\title{
Kan et frivilligt samleje være strafbart? ${ }^{1}$
}

\author{
- Overvejelser om viljens nye betydning for \\ gerningsindholdet i voldtægtsbestemmelsen
}

Clara Juul Holm, ph.d.-stipendiat ved Københavns Universitet

\begin{abstract}
:
This article examines some conceptual challenges associated with the content and possible demarcation of the notions of consent and voluntariness in recent Danish legislation on rape. It is argued that free will or voluntariness, and the expression thereof, should be seen as occurrences on a spectrum, and that the expression of consent or free will is at least partially necessary if such subjective concepts are to be useful in a legal context. The paper examines some general implications of this for possible outcomes of case law. Uncertainties include what should be made of the use of the "presumptions" mentioned in the bill. Some implications for the evaluation of a defendant's mens rea are also touched upon. It is concluded that the Danish court enjoys a margin of discretion that allows it the ability to criminalise instances of intercourse even when they are not necessarily non-voluntary.
\end{abstract}

Keywords:

Rape, voluntariness, consent, mens rea, free will.

Voldtægt, frivillighed, samtykke, forsæt, fri vilje.

»Sagen er at al denne tale om vilje og viljeserklæring ikke har det fjerneste at gøre med psykologisk beskrivelse af, hvad der foregår når en disposition foretages ... Ligesom Gudsordet skabte lyset, således skaber viljen »retten«." (Alf Ross, Om ret og retfærdighed, s. 284)

\section{Indledning}

Det forekommer umiddelbart som både simpelt og indlysende hensynsfuldt at kræve, at den, man har samleje med, skal være indforstået, og at det må udformes som krav om samtykke eller frivillighed. Sådanne krav kan imidlertid

1. Title in English: Can voluntary intercourse be a crime? 
give anledning til tvivl om, i hvilket omfang et samleje, der ikke er ufrivilligt, kan straffes.

Den 1. januar 2021 trådte en lov om ny, samtykkebaseret voldtægtsbestemmelse i kraft i Danmark. ${ }^{2}$ Straffelovens § 216, stk. 1, lyder herefter således:

»For voldtægt straffes med fængsel indtil 8 år den, der har samleje med en person, der ikke har samtykket heri. "

Forslaget til loven blev fremsat efter Straffelovrådets afgivelse af betænkning 1574 om en frivillighedsbaseret voldtægtsbestemmelse fra februar 2020. Straffelovrådets flertal anbefalede en bestemmelse baseret på et kriterium om frivillighed. Et mindretal bestående af professor i strafferet ved Københavns Universitet Trine Baumbach anbefalede at konstituere bestemmelsen omkring begrebet samtykke.

Domstolene står over for at foretage nogle valg inden for en skønsmargin, de er tildelt, som følge af samtykke- og viljesbegrebets elasticitet.

\section{Viljen som en skala}

Det hedder i forslaget til den nye voldtægtslov:

»Om der er samtykket i et samleje beror på, om personen deltager i samlejet af egen fri vilje. Det afgørende er, at personen har haft mulighed for at tage stilling til, om vedkommende vil deltage i samlejet.« (L 85, 2020-21, s. 10 og 15.)

Hvis det er korrekt, at det er afgørende for vurderingen af, om en person deltager i samlejet af egen fri vilje, om vedkommende har haft mulighed for at sige fra, så ville der reelt ikke være tale om et krav om samtykke eller frivillighed. Der ville alene være tale om, at samlejet ikke måtte være ufrivilligt, hvilket tenderer et krav om tvangsmidler. Bestemmelsen ville ikke dække ved passivitet. Det er ikke helt til at udlede, om man må se bort fra sætningen, eller om man må udlede, at man skal være tilbageholdende med at dømme for manglende samtykke, hvis der ikke foreligger regulær tvang.

Vilje må antages at kunne forekomme i flere grader, eller måske snarere i uendelige graduationer. Det er vel tidligt erkendt for så vidt angår det kriminelle forsæt. ${ }^{3}$ Viljen til samleje må også findes i uendelige graduationer fra modvilje over ligegyldighed til stærk viljefasthed. Eksempelvis: Man ønsker det brændende. Man ønsker det. Man ønsker det vel nok. Man ønsker det måske. Man synes ikke, det er en god idé, men heller ikke nødvendigvis at ideen er dårlig. Måske vil man virkelig gerne og samtidig er det måske en vir-

2. Lov nr. 2208 af 29. december 2020 om ændring af straffeloven (Samtykkebaseret voldtægtsbestemmelse).

3. Se om flydende grænser i forsætslæren f.eks. Torps andet straffelovsudkast (Torp, 1917, s. 29) og lærebog fra 1905 (Torp, 1905, s. 389). 
kelig dårlig idé. Man kan være i en situation, hvor man oplever at måtte tage stilling hurtigere end man kan nå fasthed i sin vilje eller overskue sin indre situation fuldt ud. Endelig må der være mange situationer, hvor folk ikke gør sig specielt mange overvejelser, men handler mere end de tænker, eventuelt fordi forholdets intime karakter har stået på i længere tid.

For nogen begrebers vedkommende er der selvfølgelig i højere grad tale om en dikotomi end en skala - man er myndig eller umyndig, man har enten husket eller glemt at få sit kreditkort med sig osv. Men der er ingen grund til at mene, at noget sådant gør sig gældende for viljesbegrebet, heller ikke den seksuelle vilje.

Udtrykkene for de mange mulige subjektive indstillinger må også kunne være til stede i varierende grad. Da viljen konstateres gennem udtryk, er der i praktisk henseende et sammenfald mellem graden af viljestilslutning og udtrykket herfor.

Man kan beskrive lovændringen sådan, at en betragtelig del af skalaen over viljestilslutning i seksuel sammenhæng er blevet kriminaliseret at handle inden for.

Overvejelserne her om mulige tankemåder er af samme type, som dem man allerede må gøre sig i retslivet på mange forskellige områder, hvor subjektive forhold, herunder vilje, vurderes.

\section{Begreber om en skala: Samtykke, frivillighed, ikke ufrivillighed $\mathrm{mv}$.}

Der findes nogle mulige nuancer i begreberne "(manglende) frivillighed", »ufrivillighed« og »samtykke«, som vist ikke tidligere er blevet belyst, og som har sammenhæng med at se viljen som en skala.

Indledningsvis kan det anføres, at »[b]egrebet frivillighed er udtryk for, at en person deltager af sin egen frie vilje«, som Straffelovrådets flertal skrev i 2020 Forståelsen er i overensstemmelse med ordbøgernes for så vidt angår bl.a. de skandinaviske sprog.

Man kunne overveje, om begreber som »valg« eller »at vælge« er mere relevante for voldtægtsbestemmelsens frivillighedsbegreb end «vilje« eller »at ville«. Petter Asp har hævdet, »att samtycke inte i första hand har att göra med vad man vill utan vad man väljer eller godtar »og at »[samtykke] beror emellertid inte på at jag vill (har en positiv inställning till att) [ ... ] utan på att jag accepterar att göra det. Min accept är emedlertid inte (ensam) tillräcklig för att vi ska säga att jag har samtyckt. För att jag ska ha samtyckt förutsätts inte bara att jag har sagt ja, utan att jag har sagt ja, eller accepterat, under sådana förutsättningar att vi är beredda att se mitt ja som ett uttryck för självbestämmande.« (Asp, 2013, s. 960).

Lovmotiverne bag ændringerne af voldtægtslovgivningerne i både Danmark og Sverige lægger vægt på begreberne »fri vilje« og »vilja« (f.eks. L 85, 
2020-21, s. 3, 910 og 15; Prop. 2017/18:177, s. 32-34). Begrebet »at vælge« adskiller sig vel mest nærliggende fra »at ville« ved, at man vælger blandt muligheder, imens det langt fra er sikkert, at man har muligheden for opnå de ting, man vil. Begreberne »at ville« og "at vælge« kan man bestemme sig for at tillægge specifikke betydninger ud over deres bredeste betydning. Man kan for eksempel fortælle, at man egentlig ikke ville noget, men så gjorde man det alligevel. Man ville egentlig ikke spise kagen, en kollega tog med, men så gjorde man det alligevel osv. Det betyder ikke, at man kan hævde, at det gjorte ikke var med vilje, eller at man ikke i en eller anden forstand ville det, man gjorde. Det er uanset om der indgik overtalelse eller ej. Formuleringsmetoden er en måde at fortælle om sin ambivalens. Man kan bruge udtrykket »vilje« om en stærk vilje og udtrykket »vælge« om alt det andet på viljesskalaen, man vil henregne til frivillighed (under forudsætning af at valget tillige er »udtryk for selvbestemmelse«). Man kan ligeså godt tale om stærk og svag vilje. Indbygget i viljes-begrebet ligger også, at der foreligger en tilslutning, og man kan derfor med viljesbegrebet overflødiggøre det ekstra vilkår om, at valget skal kunne ses som udtryk for »selvbestemmelse«.

At vilje kan bruges som samlebetegnelse kan illustreres af et eksempel, som Petter Asp anvender til at understøtte sin påstand: Hvis nogen bliver overtalt til at skrive en artikel, så vil de ifølge Asp stadig ikke skrive artiklen, uanset at de vælger at gøre det (Asp, 2013, s. 960). Kan det ikke tænkes, at den fiktive forfatter er blevet præsenteret for så gode argumenter, at den nu gerne vil skrive artiklen? Hvor meget overtalelse må der indgå i valget, før forfatteren ikke kan siges at ville skrive artiklen? Kan man afgøre, om forfatteren gerne »vil« skrive artiklen, eller om forfatteren kun valgte at gøre det? Og har forfatteren selv nødvendigvis en idé om det? Som udenforstående kan man nærliggende kun konstatere, at forfatteren satte sig til tasterne, dog uden at være tvunget til det. Det er oplagt i stedet at beskrive eksemplets situation sådan, at overtalelsen har flyttet forfatterens viljestilslutning hen ad en skala for vilje. Har overtalelsen kun flyttet lidt ved viljen, kan det være at forfatteren aldrig får skrevet sin artikel færdig. Er viljen derimod blevet meget stærk, finder forfatteren sig måske i endeløse afslag og krav om ændringer for dog at få sit vigtige budskab ud.

Ved at lade både den stærke og den svage vilje være omfattet af samlebetegnelsen »vilje«, kan man med én betegnelse diskutere indholdet af det samlede subjektive begreb, der betinger frivilligheden. Samtidig bliver det enklere at sammenholde det seksuelle frivillighedsbegreb med andre retlige områder, hvor man har diskuteret implikationerne af at tillægge vilje og intention betydning.

Man kan definere samtykke nogenlunde som man ønsker, som bl.a. påpeget af Petter Asp og forarbejderne til den nyeste svenske voldtægtslov (Asp, 2010, s. 205; Prop. 2017/18:177, s. 95.) I Sverige har man siden 1. juli 2018 valgt at kriminalisere samleje mv. »med en person som inte deltar frivilligt« (Brottsbalken, nr. 1962:700, kapitel 6, §§ 1, 1 a og 2). 
Samtykke kan opfattes som en retlig standard, der er forskellig fra viljen. Altså et begreb, der giver mulighed for at kræve noget andet og mere end efter begrebet "frivillighed « alene. At begrebet samtykke bærer præg af noget formaliseret er anført af både flertallet i Bet. 1574/2020 og implicit af Straffelovrådet i 2012 (Bet. 1574/2020, s. 137 og Bet. 1534/2012, s. 130). At samtykkebegrebet er formelt, imens viljesbegrebet er materielt, giver mulighed for at definere samtykke på en måde, så det indebærer formaliserede krav i tillæg til et krav om at det skal dække over fri vilje, uanset i hvilket omfang man ved den konkrete definition af et seksuelt samtykke udnytter denne mulighed for formalisering. ${ }^{4}$

Det har været hævdet, at når samtykke kan omfatte det stiltiende samtykke, så er »forskellen [på samtykke og frivillighed] forholdsvis begrænset i praksis, hvis overhovedet eksisterende. "(Vestergaard, Juristen, 2020, s. 127). Tanken er nærliggende, men næppe helt dækkende. Ikke fordi forskellen ikke kan være begrænset i praksis, henset til begrebernes sproglige elasticitet, men fordi begrebet samtykke åbner for at inddrage noget andet og mere end frivillighedsbegrebet. Det skal også vise sig, at man nok har gjort brug af det i den nye danske voldtægtslov.

Det gælder også for begreberne frivillighed og ufrivillighed, at det er muligt at definere det enkelte begrebs indhold på forskellige måder, uanset at visse forståelser kan virke mere oplagte end andre. I det følgende gives et bud på en fastlagt terminologi, der skelner mellem frivillighed og ikke-ufrivillighed.

For at opnå størst mulig præcision i begrebsanvendelsen, kan »ufrivillighed» og »frivillighed« anvendes om viljesskalaens to yderpunkter. »Ufrivillighed» er den sikre uvilje, et yderområde af skalaen. At lægge vægt på »ufrivillighed« i den forstand vil nærme sig at lægge vægt på tvangsmidler. »Frivillighed« er omvendt den utvetydige og helt klare vilje. At et samleje »ikke er frivilligt« vil herefter betyde, at man befinder sig et eller andet sted under den helt sikre frivillighed, men man kan principielt komme ret tæt på. At sige, at »frivillighed « ikke foreligger, eller at sige at »ufrivillighed « ikke foreligger, betyder efter denne begrebsbrug ikke, at det modsatte nødvendigvis må foreligge. Det ville være udtryk for en dikotomi. ${ }^{5}$

Når det er vigtigt at skelne, og at have et sprog for denne skelnen, er det fordi der er en væsentlig realitetsforskel i, om man kræver at et samleje skal være (udtrykt) frivilligt, eller om man alene kræver, at et samleje ikke må være (udtrykt) ufrivilligt. Straffes samleje, når det ikke er frivilligt, så kan det også straffes, når det ikke er ufrivilligt, og når der ikke er givet tilstrækkeligt udtryk for frivilligheden. Det er et grundlæggende problem, at man nødvendigvis må tage udgangspunkt i de impliceredes kommunikation eller udtryk for noget.

4. At samtykkebegrebet er formelt gælder uanset, om samtykke anføres at skulle vurderes »uformaliseret« (se Lovforslag L 85, 2020-21, pkt. 2.1.3.2).

5. Se om samtykkets dikotomi i engelsk ret James A. Roffee i artiklen When Yes Actually Means Yes (Roffee, s. 77). 
I almindelig sprogbrug er der næppe nogen større forskel på om noget ikke var frivilligt eller om det var ufrivilligt. Det gælder ikke kun vedrørende samleje. Ser man et behov for at sige, at noget ikke var frivilligt, for eksempel ens overarbejde, er det formentlig temmelig ufrivilligt. På samme måde vil en konstruktion som at noget »ikke var ufrivilligt« næppe forekomme, medmindre udtalelsen kommer fra nogen, der kan lide at benytte sig af litoter (»maden smager ikke dårligt«). Det kan derfor virke pedantisk alligevel at insistere på en skelnen.

Principielt og fagligt må der er alligevel være grund til at skelne mellem det, som er frivilligt, og det som ikke er ufrivilligt. Ellers kan man komme til sprogligt at camouflere eksistensen af området mellem udtrykkelig ufrivillighed og frivillighed, hvor både frivillighed og ufrivillighed egentlig mangler.

Der kan godt som alternativ tages det valg, at ufrivillighed skal være synonymt med manglende frivillighed. Men man kommer i så fald til et mangle et sprog for en skala med to yderområder.

Et eksempel findes hos mindretallet i Bet. 1574/2020. Trine Baumbach har angivet: „Et samtykkekrav vil endvidere få betydning for tilrettelæggelsen af bevisførelsen, idet det relevante bevistema bliver, om der forelå et (positivt) samtykke, fremfor at bevistemaet bliver det negative - manglende frivillighed (»ufrivillighed«).« (Bet. 1574/2020, s. 141). Ved at anvende udtrykkene »manglende frivillighed» og »ufrivillighed» synonymt, kan man risikere ikke at se, at der indholdsmæssigt findes to muligheder ud over et samtykkekrav. Der kommer derfor til at mangle stillingtagen til om (manglende) frivillighed skulle være mindre egnet at lægge vægt på end (manglende) samtykke, og herunder en redegørelse for, i hvilket omfang Baumbach måtte definere sit samtykkebegreb på en anden måde end som et krav om frivillighed. Det gælder, uanset om man forstår en potentiel bekymring for sammenblanding mellem ufrivillighed og manglende frivillighed i praksis. Når Straffelovrådets mindretal ville anvende ordet samtykke frem for frivillighed, er det givetvis for ikke at risikere at et krav om frivillighed skulle kunne fortolkes som et krav om ikke-ufrivillighed.

Trine Baumbach og Mette Lyster Knudsen har givet udtryk for, at den tidligere voldtægtsbestemmelse baseret på tvangsmidler indeholdt en uudtalt antagelse om frivillighed, som kunne fjernes med en samtykkebaseret bestemmelse (Baumbach og Knudsen, s. 204 f). Suzanne Wennberg har givet udtryk for tilsvarende angående tidligere svensk ret (Wennberg, s. 132). Opererer man med en skala, er et krav om ufrivillighed for straf ikke en formodning for (en specifik grad af) frivillighed. På samme måde er et krav om frivillighed for straffrihed ikke ensbetydende med, at man kun straffer det ufrivillige.

Forarbejderne til den seneste svenske voldtægtslovgivning ser heller ikke ud til at skelne. Den svenske betænkning »Ett starkare skydd för den sexuella integriteten« fra 2016 antyder muligvis en skala med et ambivalent område, idet det anføres, at kun en tydelig angivelse af, hvad der udgør frivillighed, vil være en klar lovgivning, og at lovgivning »som enbart baseras på bristande 
samtycke riskerar at bli oklar« (SOU 2016:60, s. 195). Samtidig anvendes udtrykkende »frånvaro av frivillighet« og »ofrivilligt« dog uden skelnen, hvilket indebærer den sædvanlige dikotomi. (SOU 2016:60, f.eks. s. 195 sammenholdt med s. 17 og 422).

Straffelovrådets flertal har medtaget et afsnit med overskriften »Hverken frivillighed eller ufrivillighed er kommet til udtryk." (Bet. 1574/2020, s. 179). Afsnittet tager ikke eksplicit stilling til, at eller om der findes ambivalens, men behandler situationer, hvor udtrykket for frivilligheden i hvert fald ikke er klart. Det fremgår, at flertallet foreslår at tillægge ægteskab og samliv, ikke-ligeværdighed, psykisk vold, om en situation er egnet til at virke intimiderende, og om der forinden er foregået skænderi eller slagsmål betydning. Hvis der ikke »på noget tidspunkt er foregået noget ubehageligt i relationen mellem parterne « taler det for et frivilligt samleje (Bet. 1574/2020, s. 181). Det sidste moment kunne godt fremstå som en accept af, at ambivalente og ikke helt tydelige udtryk kunne være tilstrækkeligt udtryk for frivillighed. I afsnittet behandles også frygt og tonisk immobilitet, som dog også kunne være behandlet som udtryk for ufrivillighed.

Det er selvfølgelig muligt, at de steder, hvor der ikke skelnes, skal tages som udtryk for den opfattelse, at der ikke er forskel på ufrivillighed og den deciderede frivilligheds fravær. Der er i så fald ikke argumenteret for standpunktet, som nærliggende ville kræve en redegørelse for, at det virkelig dækkede den menneskelige psykes kompleksitet.

\subsection{Krav til udtrykkelighed: Forskel på frivilligt og ikke ufrivilligt}

Det har været diskuteret både i det danske og svenske lovforberedende arbejde op til de nye voldtægtslovgivninger og i behandling af samtykkebegrebet mere generelt, om man kan kræve, at frivillighed er kommet til udtryk, og om man kan kræve kommunikation. ${ }^{6}$ (SOU 2016:60, s. 196; Prop. 2017/18:177, s. 32).

En eller anden form for manifestation af vilje (frivillighed) er et krav, der af praktiske årsager må stilles, for at det giver mening at beskæftige sig med den retligt. Hvis frivillighed ikke i et eller andet omfang er udtrykt, beskæftiger man sig netop ikke med for eksempel frivillighed, men med skalaens anden ende, at der ikke må foreligge ufrivillighed. Det siger dog ikke noget om hvordan eller hvor stærkt, viljen (frivilligheden) skal være udtrykt. I tillæg til krav om, hvordan frivillighed er kommet til udtryk, kan der i en samtykkenorm stilles yderligere krav.

Tvangsmidler var i bund og grund bare en måde at opregne, på hvilke måder ufrivillighed kunne være kommet til udtryk.

Straffelovrådets flertal skrev i bet. 1574/2020, at »Der bør ikke opstilles et krav om, at frivillighed forudsætter, at den pågældende positivt har udtrykt sin

6. Om at samtykke kræver kommunikation, se Jacobsen, 2019, og Andorsen, 1992, s. 427 ff. Der er uenighed om kravet til kommunikation, se Bechmann Christensen, 2010, s. 86-87 med henvisninger. 
vilje til at deltage i samlejet.« (Bet. 1574/2020, s. 179). Det fremgår dog samme sted, at flertallet alene mener, at (udtryk for) frivillighed også kan fremgå af situation og sammenhæng.

I de svenske lovmotiver er det angivet, at den svenske regering ikke anså et krav om, at frivillighed skal være kommet til udtryk, for hensigtsmæssigt (Prop. 2017/18:177, s. 32). Det var foreslået i den svenske betænkning, at frivillighed skulle være kommet til udtryk (SOU 2016:60, s. 196). Den svenske regerings afvisning af betænkningens forslag om, at frivillighed skal være kommet til udtryk, lød, at et sådant krav »leder till att det är straffbelagt att genomföra en sexuell handling med någon som i och för sig deltar frivilligt men som inte ger uttryck för frivilligheten.« (Prop. 2017/18:177, s. 32) Lidt længere henne i det svenske lovforslag ser man ud til alligevel at have forladt ideen, idet man skriver at »Utgångspunkten bör vara att den som deltar frivilligt i en sexuell handling ger uttryck för sin vilja att delta på något sätt och att avsaknaden av sådana uttryck normalt får förstås som att deltagandet inte är frivilligt.« (Prop. 2017/18:177, s. 33).

Det må være korrekt beskrevet i de svenske forarbejder, at der må kræves et udtryk for viljen. Det må samtidig også være korrekt anført, at det leder til, at det kan være strafbelagt at gennemføre samleje med en person, som sådan set deltager frivilligt uden at give (tilstrækkeligt) udtryk herfor (modsat Asp og Nilsson, s. 23). Netop dette kan være relevant at være opmærksom på, når det skal fastlægges, hvad der udgør et tilstrækkeligt udtryk.

\section{Baggrunden for domstolenes skønsmargin}

Den nye, danske voldtægtsbestemmelse er tilstræbt udformet formløst og med udgangspunkt i en konkret vurdering (L 85, 2020-21, s. 9 og 14). Den konkrete vurdering angår dels fri vilje, der som beskrevet dækker over et bredt spænd af indstillinger, og kan også angå nogle yderligere og ikke udtømmende opregnede formodningsregler, se herom nedenfor, afsnit 4.1.

Viljesbegrebets elasticitet og samtykkebegrebets i øvrigt usikre udstrækning nødvendiggør udfyldende domstolsskabte regler. Domstolene står over for at måtte tage en række valg. Det kan kun være på denne måde, hvis lovgiver ikke sætter overordentligt konkrete rammer for, hvad der skal forstås ved samtykkende og ikke-samtykkende adfærd. Det har man ikke ønsket eller valgt at gøre. Valgene skal dog tages, og hvis ikke af lovgiver, så af domstolene. Det kan ikke afvises, at der til vurderingen af samtykke - i tillæg til formodningsregler - vil blive stillet andre krav, der går udover, at fri vilje ikke kan udelukkes. Det kan netop rummes i den nye voldtægtsbestemmelse, fordi den er samtykkebaseret og ikke frivillighedsbaseret. Det kunne være krav til sikkerhed i udtryksmåde, herunder hvis parterne har været i et voldeligt forhold eller hvis der umiddelbart forinden er foregået et skænderi, krav om at 
parternes relation er »ligeværdig « mm. ${ }^{7}$ Sådanne forslag ses for eksempel hos Straffelovrådets flertal i bet. 1575/2020, men der er ikke taget stilling til dem i lovforslaget, udover at det er nævnt, at psykisk vold taler imod samtykke ved total passivitet. (L 85, 2020-21, s. 10 og 15.)

Tvivlen om bestemmelsens rækkevidde kan inddeles i en række delelementer, som ikke er afklaret i lovgivningsarbejdet. Det gælder betydningen af subtil eller uklar kommunikation, herunder betydning af det talte ord, hvad det vil sige at en situation er egnet til at være intimiderende, betydningen af passivitet uafhængigt af kommunikation, betydningen af forskellige former for svig, betydningen af beruselse, og hvad der kan lægges i de »formodninger«, som lovmotiver og betænkning har tillagt betydning. Der er grund til at beskæftige sig med disse situationers mulige tolkning hver især, men af pladshensyn vil jeg ikke behandle det i denne artikel. Det er et vigtigt redskab ved fortolkningen af de forskellige del-problematikker, at have gjort sig nogle grundlæggende overvejelser om, hvad der på det mere overordnede plan gør at der må være tvivl om bestemmelsens rækkevidde.

Domstolenes valg må basere sig på normer, som bevæger sig ind på det seksualmoralske område.

Selvom samtykke ifølge lovmotiverne ikke skal udtrykkes på »nogen bestemt måde« (L 85, 2020-21, pkt. 2.1.3.2), så må bestemte udtryk dog være samtykke, imens andre udtryk ikke er det. At »[s]amtykke efter voldtægtsbestemmelsen skal [ ... ] vurderes uformaliseret og ud fra en konkret og samlet vurdering " $(L$ 85, 2020-21, s. 9 og 14) ændrer ikke herved. Man kunne indvende, at et udtryk jo skal forstås konkret og situationsafhængigt: Noget kan betyde ét i én situation og andet i en anden. Det er for så vidt også korrekt, men man må holde sig to ting for øje. For det første, og vigtigst, må kontekst ses som en del af udtrykket. Nogle udtryk, inklusiv kontekst, er udtryk for samtykke, imens andre ikke er. For det andet kan man ikke nødvendigvis få fuld klarhed over kontekst, hvis parterne overhovedet kendte hinanden i forvejen. Man må sætte en grænse for, hvilken kontekst, der kan være relevant at inddrage. Har de implicerede for eksempel haft et forhold tidligere (hvilket nævnes i lovmotiverne), som nu er opløst, eller i hvert fald betragtes som opløst af den ene part, kan man ikke til fulde danne sig overblik over historikkens betydning for kommunikationen.

Man kan desuden på grund af baggrund, omgangsform mv. have forskellige forståelser af, hvilke udtryk der er samtykkende. Både involverede samt sagens professionelle aktører kan have forskellige opfattelser af, hvad en bevægelse, lyd mm. kan være udtryk for. Det fremgår af lovmotiverne, at »Handlinger, der kan være udtryk for et samtykke til samleje, vil f.eks. kunne være kys, berøringer, nydende lyde eller relevante bevægelser, f.eks. at man vender sig mod den anden person, selv hjælper til med at tage sit undertøj

7. Bet. 1574/2020 nævner ligeværd og voldelige forhold (flertallet), s. 180, hvor det dog mest nærliggende må anses for et forslag om formodning for ufrivillighed i disse tilfælde, samt jævnbyrdighed og gensidighed (mindretallet), s. 189. 
af, udfører samlejebevægelser eller lignende.« (L 85, 2020-21, s. 9 og 14.) Man kan forestille sig mange bevægelser og lyde fra den mindre initierende, hvis relevans de involverede samt sagens professionelle aktører kan have forskellige opfattelser af, både hvad angår graden af aktivitet eller passivitet, og når det kommer til, hvad aktiviteten er udtryk for.

Retssystemet bliver nødt til at objektivere vurderingen. Selv uden at kende al mulig kontekst må noget vurderes som samtykke, og andet må forstås som mangel herpå.

Ser man uklarhed i samtykkelovgivningen, skyldes det ikke alene lovforslagets konkrete og overordnede udformning, men et mere grundlæggende begrebsmæssigt problem ved at kræve vurdering af vilje i muligvis tvetydige eller ambivalente situationer, som nødvendigvis må give sig udslag i lovgivningen på den ene eller den anden måde. Det gælder dog ikke den uklarhed, der ikke angår fri vilje, men hvad der ellers hører til samtykkestandarden.

Det er af bevismæssige årsager generelt antaget, at der er en større tvivlsmargin ved vurderingen af subjektive elementer end ved objektive (Waaben, s. 65). Det må også gælde ved noget subjektivt som vilje (frivillighed) i et samtykke. Dette må ved den nye voldtægtsbestemmelse ofte skulle udnyttes: Den større tvivlsmargin giver mulighed for at foretage den nødvendige, objektiverede vurdering af vilje i en række situationer. Denne objektivering eller indførelse af en normativ, retlig standard for det lovlige samleje er ikke helt uproblematisk. Den nævnte bevismæssige tvivlsmargin ved subjektive forhold, herunder vilje til samleje, skaber netop usikkerhed om, hvilke bevisfakta der leder til den ene og den anden vurdering.

Den, der tager initiativ til samleje, vil efter en samtykkebaseret bestemmelse altid have overtrådt bestemmelsen, hvis den retlige standard for, hvornår samtykke foreligger, er overtrådt. ${ }^{8}$ Det svenske Lagråd skrev i tråd med denne opfattelse om forslaget i den svenske betænkning, at »[b]edömningen kommer att vara avhängig ett ställningstagande från den enskilde domaren av normativt slag, nämligen avseende vilket deltagande till vilka sexuella handlingar som i det aktuella fallet inte bör godkännas som fritt.« (Lagrådet, s. 4).

At vurderinger af vilje i et vist omfang må objektiveres - man må se på både de(n) involveredes forklaring om deres vilje, og hvordan man objektivt og med et normativt sigte må forstå deres handlinger - er erkendt i for eksempel aftaleretten og den bevisretlige behandling af forsætslære. (Zahle, 1994, s. 79; Bryde Andersen, s. 40, med henvisning til Ross, s. 281 og Udsen, s. 104-152). Det er vel også erkendt i lovforslagets motiver med denne sætning: »Et samtykke må - navnlig ud fra retssikkerhedsmæssige hensyn - vurderes objektivt ud fra oplysningerne om personens deltagelse i samlejet, herunder personens ord og handlinger, og ikke ud fra personens indre overbevisning." ( $L 85$ 2020-21, s. 10 og 15). Motiverne forholder sig dog ikke til den nødven-

8. Se om forskellen mellem opfattet samtykke og juridisk samtykke f.eks. Ferzan og Westen (2017). 
dige, medfølgende uklarhed eller hensigtsmæssigheden af de heraf følgende objektiverede, normative standarder.

Hvad angår samtykke og aftaler i de fleste af livets situationer, er der som udgangspunkt ikke grund til at tro, at folk skulle have nogen speciel anledning til at benytte sig af en meget individuel eller tvetydig kommunikation, der kan volde problemer for udenforstående at sætte sig ind i. I udgangspunktet står man ikke i en socialt videre kompliceret situation, hvis man vil købe en bil eller bestille et parti varer hjem til sit firma. Inddeling i konstaterende erklæring, øvrig kommunikation uden vilje og viljeserklæring kendes fra aftaleretten (Bryde Andersen, s. 76 ff.). På det seksuelle område må det være særligt svært at trække grænsen mellem en konstaterende erklæring (»det er ikke en god idé« mv.), øvrig kommunikation uden vilje (herunder lyde, bevægelser mm.) og viljeserklæringen. ${ }^{9}$ Regulering, der antager klar og for udenforstående letforståelig kommunikation, fører på seksualområdet nemmere til et materielt forkert resultat end på de fleste andre områder. Desuden er den retlige byrde ved at blive misforstået større, når den udgøres af straf. Der er derfor på området større grund til at afholde sig fra normativ ansporing til klarhed i kommunikationen. Se også om forskellen på samtykke i aftale- og erstatningsretten og i seksuelle forhold i Bet. 1534/2012, s. 130.

Man kunne tænke, at det er uproblematisk at overføre samtykkets normativitet til voldtægtsdeliktet, i betragtning af at der også må stilles krav om en vis klarhed i et samtykke, der udgør en objektiv straffrihedsgrund. Det er dog mindre oplagt som udgangspunkt at anse seksuelle handlinger for uønskede, end det er at anse for eksempel tyveri eller vold som uønsket. Der kan derfor ikke stilles samme klarhedskrav til det seksuelle samtykke som til det almindelige, strafferetlige samtykke. Det er vel også baggrunden for, at man ikke har valgt at konstruere voldtægtsbestemmelsen sådan, at samleje er forbudt, og derefter falde tilbage på almindelige regler om samtykke. For objektive straffrihedsgrunde lægges desuden en større bevisbyrde på gerningspersonen, hvilket ikke uden videre kan overføres på et gerningsindhold. Samtykkebegreberne må nødvendigvis være forskellige, men det er uklart, i hvilket omfang de er det.

Tvangsmidler, som den tidligere voldtægtsbestemmelse byggede på, var en måde at sætte konkrete rammer, der begrænsede domstolenes behov for selv at sætte normer for området.

I angelsaksisk ret har samtykkebegrebets uklarhed også været kritiseret, med varierende kritik af et seksuelt samtykkebegreb som sådan (Ashworth, s. 339; Ashworth og Temkin, s. 328-346; Tadros, s. 543; Simpson, s. 122).

Uklarheden må forventes efterhånden at mindskes af en fastere praksis for, hvad den tilstrækkelige vilje, eller det tilstrækkelige andet, i samtykkebegrebet udgøres af og skal give sig udtryk som. Det hjælper dog ikke domstolene,

9. Om vægt på lyde og bevægelser, se for eksempel L 85, 2020-21, alm. bemærkninger, pkt. 2.1.3.2. 
når de skal tage stilling, eller dem, hvis faktiske viljeskommunikation ikke er i overensstemmelse med den domstolsskabte norm.

Det her beskrevne kan også gøres gældende for så vidt angår samtykke til blufærdighedskrænkelse og tilsvarende mindre alvorlige seksualforbrydelser, hvor samtykkekrav (enten eksplicit i bestemmelsen eller implicit som straffrihedsgrund) ikke er noget nyt. Der er dog årsager til, at samtykkekrav i disse tilfælde både er mere oplagt og mindre problematisk. For det første må der antages sjældnere end ved samleje at være en form for optakt, som giver den anden en anledning til at manifestere ufrivillighed. For det andet er det mindre betænkeligt at give vide rammer for, hvornår man kan have antaget et samtykke, når det, der gives samtykke til, er mindre indgribende. Endelig er forbrydelserne mindre alvorlige, hvilket i nogen grad taler for, at man ikke behøver i samme grad at vægte tilbageholdenhed af retssikkerhedsmæssige årsager.

Jørn Vestergaard har anført følgende om, at samtykkebestemmelsen ikke kan ramme hidtil almindeligt forekommende situationer, hvor ingen ønsker samtykke:

»En deltager i debatten [Lea Korsgaard, chefredaktør for Zetland, den 27. februar 2020] gav udtryk for, at et retssamfund ikke bør kriminalisere normale handlinger, herunder tilfælde hvor ingen af parterne finder det nødvending at sikre sig et samtykke. [ ... ] Alt andet lige er der ikke noget juridisk grundlag for sådanne bekymringer; men da samtykkebegrebet som sådant er åbent for fortolkning, er der god plads til sådanne forestillinger i den offentlige diskurs.» (Vestergaard, 2020a, s. 128).

Det skulle gerne fremgå af det beskrevne, at der er juridisk grundlag for sådanne bekymringer, uanset at de debattører, Jørn Vestergaard henviser til, ikke alle er jurister. I hvilket omfang bekymringerne skal vise sig begrundede, beror på valg foretaget af domstolene, der har væsentlig skønsfrihed på området. Nogen endelig konklusion på, om det normale og gensidigt ønskede i praksis er blevet kriminaliseret, vil man dog ikke kunne nå, heller ikke når der er kommet en væsentlig mængde afgørelser. Det ville kræve enighed om, hvad der er normalt. Domstolene må dog fastlægge, hvor vide rammer der er for det - i juridisk forstand og tilstrækkeligt - normale.

Man må overveje, om ikke samtykkekravets uklarhed og karakter af en retlig standard giver det væsentlige ligheder med kriminalisering af uagtsom voldtægt. Et enigt Straffelovråd afviste i seneste betænkning at kriminalisere uagtsom voldtægt af retssikkerhedshensyn med den begrundelse, at det indebærer »en normativ vurdering, der kan være subjektivt præget, og hvori individuel seksualmoral kan indgå.« (Bet. 1574/2020, s. 154). ${ }^{10}$

10. Manglende seksuel handlenorm også anført som begrundelse i Straffelovrådets betænkning 1534/2012 om seksualforbrydelser, s. 225 og det efterfølgende lovforslag L 141 2012-13, pkt. 3.2.4. 


\subsection{Formodninger}

Ved total passivitet er der i lovmotiverne en forudsætning om »formodning" imod samtykke. Der er tale om en formodning for manglende samtykke ved »total« passivitet, som konkret kan afkræftes:

»I de situationer, hvor der er udvist total passivitet fra den ene persons side, er der en formodning for, at vedkommende ikke samtykker, og derfor må den person, der ønsker samleje gennemført, gøre noget for at sikre sig, at vedkommende samtykker. Også ved total passivitet må det dog afhænge af en konkret og samlet vurdering, om deltagelse i samlejet kan anses for at være sket med samtykke.« (L 85, 2020-21,

s. $10 \circ$ og 15.)

Ved intimiderende situationer har man beskrevet en formodningsregel i lovmotiverne: "[S]elv om sådanne [samtykkende] handlinger måtte foreligge, kan der være en formodning imod, at et samtykke foreligger. Det vil f.eks. kunne være tilfældet, hvis samlejet er gennemført under omstændigheder, der er egnet til at virke intimiderende." (L 85, 2020-21, s. 14 f.).

Det fremgår af formuleringsmåden i det citerede, at der i tillæg hertil også i andre situationer kan indlægges en formodning for, at der mangler samtykke, men det fremgår ikke hvornår.

Man kan enten se formodningsreglerne som bevismæssige, hvilket dog ville medføre en vendt bevisbyrde, eller som udtryk for at samtykkebegrebet også på disse områder er tilføjet noget i tillæg til frivillighedsvurderingen som en del af den retlige standard. Se om formodninger som bevisbyrderegler f.eks. Henrik Zahle i »Om det juridiske bevis« (Zahle, 1976, s. 274 ff. med henvisning til P.O. Ekelöf og P.O. Bolding.) Se også f.eks. The burden of proof (Dine, s. 19 ff.) og Phipson on Evidence (Phipson, Malek og Auburn, s. 7 og 171-172).

\section{Forsæt: Tiltalte må (også) gives bred skønsmargin}

Den nævnte situation kompliceres af vanskeligheden af, at gerningsmandens forsæt skal tages i betragtning.

Med alle muligheder for talt og uudtalt kommunikation - ord, kropssprog, lyde, intonation, tidligere adfærd, samtidig adfærd, og mangel på samme - kan folk udtrykke hele det lange og mudrede spektrum af vilje på en kontekstafhængig måde i en af livets mest private situationer. Man skal på én gang beskæftige sig med offerets vilje bag den muligt samtykkende handling, som altså på grund af emnets natur er forbundet med stor vanskelighed, og med gerningsmandens forståelse af denne i sig selv vanskelige vurdering. Den tiltalte må af den grund enten gives en særlig bred margin for at opfatte en tvetydig situation anderledes end den anmeldende og domstolen, eller også er der tale om en særligt bred bevismargin, som ikke nødvendigvis fører til et materielt korrekt resultat. 
Det gælder særligt, når det ikke til manglende samtykke hører, at der er sagt fra eller på anden måde givet udtryk for ufrivillighed (en såkaldt »no means no«-model). ${ }^{11}$ Høje krav til et samtykkes udtrykkelighed ville til dels afhjælpe vanskeligheden ved at vurdere (forsæt til) andres vilje. Med lovforslagets bemærkningers vægt på den frie vilje som forudsætning for samtykke, får man ikke afhjulpet viljes-problemet (L 85, 2020-21, s. 10 og 15).

Visse danske politikere har ønsket, at der i samtykkekravet indgår et krav om, at man stiller spørgsmål ved tvivl om samtykke til et samleje. ${ }^{12}$ Når deliktet foreligger i forsætlig form (som i Danmark), kan det ikke være løsningen på spørgsmålet om, hvad man skal stille op med potentiel uklarhed. Det strider imod forsætskravet at kræve fuldstændig afklaring ved tvivl, da forsæt til den andens manglende vilje til samleje ikke nødvendigvis afgøres af, om der er stillet et spørgsmål eller ej. At tillægge det afgørende betydning, om der er stillet spørgsmål i en tvivlssituation, er en uagtsomhedsstandard: Burde du have vidst, der ikke var samtykke (og dermed også have spurgt)? Det ville desuden stille krav til samtykkets sikkerhed, som ligger udover, hvad der er forudsat i de danske lovmotiver for så vidt angår passivitet. I lande, som har kriminaliseret groft uagtsom voldtægt, må det dog være muligt at lade det indgå som negativ faktor i skyldsvurderingen efter uagtsomhedsdeliktet, at der ikke er stillet et spørgsmål. I forarbejderne til den svenske voldtægtsbestemmelse, som også findes i uagtsom form, står: „Om det uppstår osäkerhet får gärningsmannen förvissa sig om att deltagandet är frivilligt.« (Prop. 2017/18:177, s. 34). Et sådant krav om spørgsmål eller anden sikkerhed kan dog ikke stilles som betingelse for at undgå ansvar for forsætlig voldtægt.

\section{At stå i et slutpunkt eller at vælge et punkt på en skala}

Petter Asp og Göran Nilsson har skrevet om den svenske model, at „2018 års reform [kan] ses som en naturlig slutpunkt (självfallet kommer lagstiftningen att ändras också framöver, men det är en slutpunkt på så sätt att reformen innebär en övergång till en delvis ny form av reglering) i en utveckling där allt mer vikt lagts vid att det sexuella självbestämmandet har kränkts och mindre vikt lagts vid hur det kränkts (om det skett genom våld, hot, utnyttjande, vilseledande etc.) »(Asp og Nilsson, s. 8.) (13 $^{13}$ Man kan overveje, i hvilket omfang svensk ret har placeret sig i et slutpunkt. Hvis man ser «slutpunktet« som den

11. Om balancering af parternes pligter, se Jørn Jacobsen i Valdtektsstraffebodet (Jacobsen, s. 315). Se om acceptabelt samleje som samtykkestandard hos Petter Asp i Sex och Samtycke (Asp, 2010, s. 158 ff.) Den svenske Sexualbrottskomités foreslog at kun ja skulle betyde ja (SOU 2016:60, s. 196). Se om "yes means yes" f.eks. hos Kimberley Ferzan, Consent, Culpability, and the Law of Rapes (Ferzan, s. 397-439).

12. Se for eksempel nyhed på dr.dk, https://www.dr.dk/nyheder/politik/paastand-modpaastand-kraever-sex-en-kontrakt-vi-har-bedt-fire-politikere-forklare.

13. I SOU 2016:60 s. 117 skrives at samtykkeregulering «innebära en naturlig fortsättning av utvecklingen». 
højest mulige sikring af størst mulig viljestilslutning til samleje, har svensk ret ikke placeret sig så meget i et slutpunkt som dansk ret har. Frivillighed vil efter svensk lovgivning altid være tilstrækkeligt, hvilket som beskrevet ikke altid er tilfældet efter dansk rets samtykkenorm, hvor der yderligere findes bl.a. formodningsregler.

Man kan forestille sig et »slutpunkt«, der ligger endnu længere henne på skalaen end det danske. Man kan anlægge en - potentielt uendeligt - mere formalistisk tilgang til vilje og samtykke, herunder opstille flere formodninger for, hvornår noget ikke er frivilligt. Det er politisk vilje, der gør, at man ikke har placeret sig i et egentligt slutpunkt. Ikke at en skala har mødt en teoretisk mur eller absolut endestation.

Man må på denne baggrund også anerkende, at der ikke retligt kan gives nogen entydig anvisning på, hvilken regulering der i højest mulig grad tilgodeser individets ret til at forme eget liv. Erkendelsen kan tillige have den praktiske betydning, at man i vurderingen af tvivlstilfælde i praksis ikke kommer til at bruge den fejlslutning, at en voldtægtslovgivning, der ikke baserer sig på tvangsmidler, nødvendigvis skal anvendes på en sådan måde, at ingen tvivl om absolut frivillighed må være tilbage. Det kan virke som et efterstræbelsesværdigt udgangspunkt at undgå tvivl om frivillighed, men er netop i muligt tvivlsomme situationer ikke nødvendigvis, hvad der skal lægges vægt på - selv ikke efter en lovgivning, der vægter det forholdsvist højt, at der skal være givet udtryk for frivillighed - af den grund, at det også vil ramme endog særdeles frivillig adfærd. For overvejelser i denne retning, se bl.a. Jørn Jacobsen og Henriette Sinding Aasens beskrivelse af at der findes både en negativ selvråderet, retten til ikke at blive udsat for overgreb, og en positiv selvråderet, som er retten til at disponere frit over sin krop og seksuelle liv. ${ }^{14}$ (Jacobsen, s. 314; Jacobsen og Sinding Aasen).

Svensk praksis kan se ud til at have valgt at snævert viljesbegreb (se mål nr. B 1200-19 for Högsta Domstolen). Det er ikke givet, at danske domstole i konkrete situationer vil navigere på samme måde inden for det råderum, uklarheden giver. Island fik ny voldtægtsbestemmelse baseret på samtykke i 2018 (Lov af 5. april 2018 om ændring af den almene straffelov nr. 19/1940 med efterfølgende ændringer (seksuelle overtrædelser)). Når man ser på Ragnheiður Bragadóttirs gennemgang af islandsk praksis fra 2019, kunne noget tyde på, at man i Island har valgt et bredere afgrænset samtykkebegreb (Bragadóttir, s. 183 ff).

\section{Afrunding}

Med en voldtægtsbestemmelse, som beror på samtykke og vilje, må man nødvendigvis overlade domstolene en bred skønsmargin. Samtidig må man

14. Med henvisning til Alan Wertheimer, Consent to Sexual Relations, 2003. 
ofte stå med situationer, som må afgøres ud fra en objektiveret retlig standard eller norm. Altså situationer, hvor man ikke egentlig kan blive sikker på de impliceredes (manglende) vilje, men betragter noget som utilstedeligt i seksuel sammenhæng. Det gælder særligt, da man har valgt et seksuelt samtykkebegreb centreret om frivillighed i stedet for at nøjes med et krav om, at samlejet ikke må være ufrivilligt. Med den nye danske bestemmelse lægges vægten desuden ikke nødvendigvis på, hvad folk vil, men hvad de anses for at have samtykket i.

For at besvare artiklens overskrift: Et frivilligt samleje kan ikke straffes, i hvert fald ikke hvor frivilligheden i høj grad er udtrykt. Men domstolene må vælge, i hvilken udstrækning man kan straffe samleje, der ikke er ufrivilligt.

Kontaktoplysninger

Clara Juul Holm: clara.juul.holm@jur.ku.dk

\section{Litteratur}

Ashworth, A., (2009). Principles of Criminal Law. 6. udgave. England: Oxford University Press. Ashworth, A. og Temkin, J., (2004). The Sexual Offences Act 2003: (1) Rape, sexual assaults and the problems of consent, Criminal Law Review, s. 328-346.

Asp, P., (2010). Sex och samtycke. Uppsala: lustus.

Asp, P., (2013). Sex och samtycke - et lagstiftningsteknisk fråga. Juridisk Tidskrift. Nr. 4 2013/14, s. 959-968.

Asp, P. og Nilsson, G., (2018). Brottsbalken 6 kap. - En kommentar. Stockholm: Karnov Group Sweden AB.

Andorsen, K. V., (1992). Strafferettslig samtykke. Tidsskrift for Rettsvitenskap, s. 104-152. https://doi.org/10.18261/ISSN1504-3096-1992-03-04-01

Baumbach, T. og Lyster Knudsen, M., (2019). Bevis i straffesager. I: Retsplejeloven 100 år. Rammeskow Bang-Pedersen, U., Baumbach, T., Scharf, O., Stevnsborg H. (eds.) Danmark: DJØF forlag.

Bragadóttir, R., (2019). Sex uden samtykke - udviklingen i islandsk ret. Nordisk Tidsskrift for Kriminalret, nr. 2/2019, s. 175-187. https://doi.org/10.7146/ntfk.v106i2.124775

Bryde Andersen, M., (2013). Grundlæggende aftaleret. 4. udgave. København: Gjellerup.

Christensen, M. B., (2008). Det strafferetlige samtykke. Danmark: Jurist- og Økonomforbundets Forlag.

Danmarks Radio, (2020). Påstand mod påstand? Kræver sex en kontrakt? Vi har bedt fire politikere forklare ny samtykkelov. Nyhedsartikel. Tilgængelig på https://www.dr.dk/ nyheder/politik/paastand-mod-paastand-kraever-sex-en-kontrakt-vi-har-bedt-fire-politikere-forklare.

Dine, J. (1987). Criminal law. I: The burden of proof. Kiralfy, A., ed. Indiana: Professional Books.

Ferzan, K. Consent., (2016). Culpability, and the Law of Rape. Ohio State Journal of Criminal Law, Vol. 80, nr. 3, s. 397-439.

Ferzan, K. Og Westen, P., (2017). How to Think (Like a Lawyer) About Rape. Criminal Law and Philosophy 11(4), s. 759-800. https://doi.org/10.1007/s11572-016-9404-7. https://doi. org/10.1007/s11572-016-9404-7

Jacobsen, J., (2019). Valdtektsstraffebodet. Gjeldande rett og spørsmålet om reform. Norge: Fagbokforlaget.

Jacobsen, J. og Aasen, H. S., (2018). Valdtektsdebatten må opp av skyttargravene. Tilgængelig på https://agendamagasin.no/kommentarer/valdtektsdebatten-skyttargravene/ 
Phipson, S. L. \& Malek, H. \& Auburn, J., (2013). Phipson on Evidence, 18. reviderede udgave. UK: Sweet \& Maxwell.

Ross, A., (1953). Om ret og retfærdighed. 2. udgave. København: Hans Reitzels Forlag.

Roffee, J. A., (2015). When Yes Actually Means Yes. I: Powell A., Henry N., Flynn. A. (eds) Rape Justice. S. 77. London: Palgrave Macmillan. https://doi.org/10.1057/9781137476159.0009 https://doi.org/10.1057/9781137476159.0009

Simpson, B., (2016). Why has the Concept of Consent Proven So Difficult to Clarify? The Journal of Criminal Law 80(2), s. 97-123. https://doi.org/10.1177/0022018316639104 https://doi.org/10.1177/0022018316639104

Tadros, V., (2006). Rape without Consent, Oxford Journal of Legal Studies 26(3), s. 515-543. https://doi.org/10.1093/ojls/gql016 https://doi.org/10.1093/ojls/gql016

Torp, C., (1905). Den danske Strafferets Almindelige Del. København: Gad.

Torp, C., (1917). Straffelovudkast U II.

Udsen, H., (2006). Uagtsomhed som aftalestiftende retsfaktum - et bidrag til den aftaleretlige forpligtelseslære. Tidsskrift for Rettsvitenskap, s. 104-152. https://doi.org/10.18261/ ISSN1504-3096-2006-01-03

Vestergaard, J., (2020). Voldtægtsparagraffen. Juristen, nr. 3/2020.

Wennberg, S., (2004). Våldtäkt - med eller mot kvinnans vilja? Juridisk Tidskrift. Nr 1 2004/05, s. 113-131. https://doi.org/10.5594/J15193

Waaben, K., (1957). Det kriminelle forsæt, 1957. København: Gyldendal.

Zahle, H., (1976). Om det juridiske bevis. København: Juristforbundets Forlag.

Zahle, H., (1994). Bevisret Oversigt. København: Jurist- og Økonomforbundets Forlag.

Straffelovrådets betænkning 1534/2012 om seksualforbrydelser.

Statens offentliga utredningar (SOU) 2016:60, Ett starkare skydd för den sexuella integriteten.

Svensk proposition 2017/18:177, En ny sexualbrottslagstiftning byggd på frivillighet.

Lagrådet, Utdrag ur protokoll vid sammanträde 2018-01-23, s. 4.

Straffelovrådets betænkning 1574/2020 om en frivillighedsbaseret voldtægtsbestemmelse.

L 85 Forslag til lov om ændring af straffeloven (Samtykkebaseret voldtægtsbestemmelse), 2020-21.

Högsta Domstolens mål nr. B 1200-19.

Lov af 5. april 2018 om ændring af den almene straffelov nr. 19/1940 med efterfølgende ændringer (seksuelle overtrædelser). Islandsk. https://www.althingi.is/altext/148/s/0638.html

Lag om ändring i brottsbalken, trådt i kraft 1. juli 2018. Svensk författningssamling 2018:601, https://svenskforfattningssamling.se/sites/default/files/sfs/2018-05/SFS2018-601.pdf

Lov nr. 2208 af 29. december 2020 om ændring af straffeloven (Samtykkebaseret voldtægtsbestemmelse). 